\title{
Bir Semptom ve Bir Hastalık Olarak Uykusuzluk
}

\section{Insomnia as a Symptom or a Disease}

\author{
Sinan Yetkin, Hamdullah Aydın* \\ Gülhane Askeri Tıp Akademisi, Psikiyatri Anabilim Dall, Ankara, Türkiye \\ *Uyku Günlüğü, Uyku Araştırma Merkezi, Ankara, Türkiye
}

\begin{abstract}
Özet
Uykusuzluk, bireylerin fiziksel, psikolojik ve sosyal performansları ve yaşam kaliteleri üzerinde olumsuz etkilemesi nedeniyle önemli bir halk sağlığı sorunudur. Doğrudan uyku ve uyanıklığı düzenleyen mekanizmalardaki bir bozukluktan veya dolaylı olarak eşlik eden psikiyatrik ya da tıbbi durumlardan kaynaklanabilir. Eşlik ettiği tabloların klinik yapısını, tedavi yanıtını ve prognozunu olumsuz yönde etkilediği de bilinmektedir. Ancak çoğu zaman bir hastalıktan çok bir semptom olarak değerlendirilmekte ve tedavi edilmektedir. Uykusuzluk olgularının birincil veya ikincil olup olmadığı her zaman belirgin değildir. Fakat uykusuzluğun bir hastalık (birincil) veya bir semptom (ikincil) olduğunun ayrımı etyopatogenezin daha iyi anlaşılması için gereklidir. Aynı zamanda uygun ve etkili tedavinin seçimi için de önemlidir. Bu nedenle, uykusuzluk olgularının sistematik bir şekilde değerlendirilmesi gerekir. (JTSM 2014;1:1-8) Anahtar Kelimeler: Uykusuzluk, birincil uykusuzluk, ikincil uykusuzluk, hastalık, semptom
\end{abstract}

\begin{abstract}
Summary
Insomnia is an important public health problem because it has a significant negative impact on individuals' physical, psychological, and social performance, and quality of life. It may arise directly from a sleepwake regulatory dysfunction and/or indirectly result from comorbid psychiatric or medical conditions. It is also known that insomnia as a symptom has a negative impact on clinical structure, response to therapeutic intervention, and prognosis of co-morbid pathology. However, it has generally been viewed and treated as a symptom rather than disease. It is not always clear which insomnia cases are primary and which are secondary. But the distinction between insomnia as a disease (primary) and as a symptom (secondary) is essential for better conceptualization of the condition for etiopathogenesis, and it is also important for choosing the most appropriate and effective therapy. For these reasons, a systematic evaluation of insomnia cases is needed. (JTSM 2014;1:1-8)
\end{abstract}

Key Words: Insomnia, primary insomnia, secondary insomnia, disease, symptom

\section{Giriş}

Araştırmalar, uykusuzluğun öngörülerin ötesinde yaygın bir sorun olduğunu ortaya koymuştur. Uykusuzluk, nasıl ortaya çıkıyor olursa olsun, yaşam kalitesini etkileyen, eşlik ettiği tabloların yapısını, gidişini ve prognozunu kötüleştiren ciddi bir sağlık sorunudur. $\mathrm{Bu}$ makalede öncelikle, bir semptom olarak uykusuzluk irdelendikten sonra bir hastalık olarak uykusuzluk ele alınacaktır. Bu noktada, kısa uyuyanlar ve ikincil uykusuzluk öncelikli olarak ele alınmamaktadır. Kısa uyuyanlar, normalden az uyumalarına karşın dinlenmiş olarak gündelik yaşamda yer alabilmektedirler. Yaşamları boyunca bu şekilde uyuyanlardan farkı olarak, zaman zaman özel nedenlerle az uyuyanların bu grup içinde ele alınması söz konusu değildir. İkincil uykusuzluk ise, bir nedenle ilişkili olarak gelişen ve bu nedenin ortadan kalkmasıyla düzelen tablolardır.

\section{Bir Semptom Olarak Uykusuzluk}

Tetikleyici faktör olarak ele alındığında, bir nedenle oluşan uykusuzluk, bir hastalı̆̆ın ortaya çıkısını tetikleyebilmektedir. Öte yandan, bir hastalık öncelikle uyku yapılanmasını etkileyerek bozulmasına yol açabilir.

Hastalıkta belirti olarak görülen uykusuzluk, aynı faktörün hastalığı ve uykuyu eş zamanlı olarak bozması sonucu gelişen tablolar şeklinde olabilmektedir. Genellikle hastalıkların, kullanılan ilaçların uykusuzluğa yol açtığı bilinmektedir.

Bir hastalığın tedavisi tamamlandıktan sonra, kalıntı denilebilecek silik düzensizliklerin, aynı hastalı̆̆ın yeniden ortaya çıkması için uygun bir ortam olduğu kabul edilmektedir. Bu bozulmalar uykuyla ilişkili alanda olduğunda bir kalıntı belirti olarak uykusuzluk gelişme olasılığı yüksektir (Tablo 1).

\section{Bir Hastalık Olarak Uykusuzluk}

Uykusuzluk, tüm hastalıklara sıklıkla eşlik edişi nedeniyle, ikincil uykusuzluktan farklı bir tablo olduğunun anlaşılması zaman almıştır. Kendi içinde sınırları çizilebilen bu tablo son yıllarda, sınıflamalarda "birincil uykusuzluk" olarak yer almıştır. 
Amerikan Uyku Tıbbı Akademisi'nin Uluslararası Uyku Bozuklukları Sınıflama kitabında, birincil uykusuzluk tanımı, "uyuyabilmek için koşullar uygun olmasına karşın, uykunun başlamasında, sürmesinde, bütünlüğü ya da kalitesinde tekrarlayıcı bozulmalara ek olarak gündelik yaşamda sorunlarla kendini gösteren bir tablo" olarak verilmiştir (1).

Uykusuzluk, üç temel biçimde kliniğe yansımaktadır: Uykuya dalma güçlüğü, uyku sürekliliğinde bozulma ve uykunun sonlanmasında ortaya çıkan sorun.

\section{a. Uykuya Dalma Sorunu Sonucu Olarak Uykusuzluk}

Sağlıklı bireylerin, uykuya dalma öncesinde, kısa süre içinde, gün içinde yaşadıkları olayları gözden geçirdikleri bilinmektedir. Bu işlem, gün içinde yaşananlardan yola çıkarak anıların bellekteki bilgilerle bütünleştirilmesine aracılık etmektedir. Bu akış, birincil uykusuzluk çerçevesinde ele alındığında bu bireylerin iki özelliği ön plana çıkmaktadır: Birincisi, birincil uykusuzlukta, uykuya dalma güçlüğü nedeniyle uyanıklıktan uykuya geçiş süresi uzamaktadır. Bu geçiş aralığında, bir ölçüde farklı bilinçlilik içinde oluş, yaşantıların gözden geçirilişine yansıyabilmekte ve işlemler değişebilmektedir (2). Düşünce ve duygu süreçleri de bu farklıık içinde, kendine özgü bir işleyiş içinde olmaktadır. Bu nedenle, gün içinde, o koşullar içinde, önemsenmemiş bir konu yeniden ön plana çıkabilmektedir. Çoğu zaman hastalar bu durumu, "birden aklıma takılan bir konu nedeniyle, sanki saatlerce uyumuş gibi gözlerim açlıveriyor ve uyuyamıyorum" şeklinde ifade etmektedirler.

Uykuya dalma güçlüğü olanlarda, belirgin tetikleyici olaylar dışında, özellikle aşağıdaki iki alan üzerinde durulabilir: Huzursuz bacaklar sendromu ve uyku-uyanıklık ritmi bozuklukları.
Huzursuz bacaklar sendromu (HBS): HBS, dinlenme döneminde ortaya çıkan, gece artan ve bacakların diz altı bölgelerinde algılanan huzursuzluk hissiyle karakterize bir bozukluktur (Tablo 2).

Uluslararası HBS grubu, dört tanı ölçütü belirlemiştir (3):

a. Parestezi nedeniyle bacakları hareket ettirme isteği

b. Motor huzursuzluk

c. Belirtilerin geceleri kötüleşmesi

d. Belirtilerin, dinlenme sırasında artması, aktivite ile azalması Uyku-uyanıklık ritim bozukluğu: Bu bozuklukta uykuya dalma aksamaktadır. Sorun hastalar tarafından "aslında uykum var gibi oluyor ama yattığım zaman uykuya dalamıyorum, gözlerim açılıveriyor" şeklinde ifade edilmektedir. Bu hastalar, gecenin ilerleyen saatlerinde uykuya dalabilmekte, gündüzün büyük bir bölümünü uykuda geçirmektedirler. Böylece, uyku-uyanıklık ritmindeki bozulma giderek pekişmektedir (4).

$\mathrm{Bu}$ grupta, vardiya usulü çalışanların ayrıca ele alınması gerekmektedir. Çalışma saatlerinin gecede olduğu dönemlerden sonra gündüz vardiyasına geçildiğinde, gece olağan zamanda uyumanın düzenlenmesi, genellikle günler içinde tamamlanmaktadır. Bu düzenleme tamamlansa bile, yeniden gece vardiyasına dönülmesiyle uyku-uyanıklık ritmi değişmektedir. Yıllarca süren bu değişimler sonrasında ana ritim bozulabilmekte, uygun zaman dilimlerinde uykuya dalmada sorunlar yaşanmaktadır.

Çoğu ergen, gece saatlerini görece daha canlı yaşamakta, geç saatlerde ya da sabaha karşı uyuyarak günün bir bölümünü uykuda geçirmektedir. Bir tür sirkadiyen ritim kayması gibi değerlendirilebilecek bu durum genellikle zaman içinde ortadan kalkmaktadır.

Tablo 1. Bir semptom olarak uykusuzluk

\begin{tabular}{|c|c|c|}
\hline Tetikleyici faktör olarak & Hastalıkta belirti olarak & Hastalığın kalıntı belirtisi olarak \\
\hline $\begin{array}{l}\text { Uykunun farklı nedenlerle bozulmasının } \\
\text { diğer hastalığı tetikleyiciliği } \\
\text { Uykusuzluk ile diğer hastalık gelişiminin ortak } \\
\text { ögelerle olması (uykusuzluk ilk semptom olarak } \\
\text { haber verici gibidir) }\end{array}$ & $\begin{array}{l}\text { Ortak nedenlerle gelişen uykusuzluk } \\
\text { Hastalığın yol açtığı değişmeler ya da } \\
\text { uyarılmışlık sonucu gelişen uykusuzluk } \\
\text { Tedavinin yan etkisi olarak gelişen uykusuzluk }\end{array}$ & $\begin{array}{l}\text { Hastalık sırasında gelişen uykusuzluğun, } \\
\text { tedavi sonrasında da kalıcı oluşu } \\
\text { Özellikle tekrarlayan hastalıklardan } \\
\text { artakalan uykusuzluk }\end{array}$ \\
\hline
\end{tabular}

Tablo 2. Huzursuz bacaklar sendromu belirtileri

\begin{tabular}{|l|l|l|}
\hline Temel belirtiler & Destekleyici veriler & ilişkili veriler \\
\hline $\begin{array}{l}\text { Genellikle bacaklarda, rahatsılık } \\
\text { hisleri ve hareket ettirme gereksinimi olması }\end{array}$ & $\begin{array}{l}\text { Otozomal dominant geçişe işaret } \\
\text { edebilecek aile öyküsü bulunması }\end{array}$ & $\begin{array}{l}\text { Temel olarak, kronik ve ilerleyici olmakla } \\
\text { birlikte, bazı hastalarda bir ay } \\
\text { kadar süren iyilik dönemleri olabilir }\end{array}$ \\
\hline $\begin{array}{l}\text { Bu hislerin istirahat sırasında } \\
\text { ortaya çıkması ya da artması }\end{array}$ & $\begin{array}{l}\text { Dopaminerjik tedaviye } \\
\text { olumlu yanıt vermesi }\end{array}$ & Fizik muayenenin normal olması \\
\hline $\begin{array}{l}\text { Bu hislerin, hareketle azalması ya da } \\
\text { ortadan kalkması ve hareket sürdükçe } \\
\text { rahatlamanın sürmesi }\end{array}$ & $\begin{array}{l}\text { Uyanıklıkta ya da uykuda özellikle bacaklarda, } \\
\text { bazen de kollarda periyodik hareketler olması }\end{array}$ & $\begin{array}{l}\text { Uykusuzluğa yol açacak şekilde } \\
\text { periyodik bacak hareketleri olabilir }\end{array}$ \\
\hline $\begin{array}{l}\text { Bu hislerin, akşam saatlerinde artması } \\
\text { ya da sadece akşam saatlerinde ortaya çıkması }\end{array}$ & & $\begin{array}{l}\text { Her yaşta görülebilirse de vgenellikle } \\
\text { orta ve ileri yaşta ortaya çıkması }\end{array}$ \\
\hline & Düşük ferritin düzeyi (<50 $\mu \mathrm{gg} / \mathrm{L})$ olabilir \\
\hline
\end{tabular}


b. Uyku Sürekliliğinde Bozulma Sonucu Olarak Uykusuzluk Uyku sürekliliğinin bozulduğu tablolarda, uyarılmışlık ve uyanıklıklar yoğun bir şekilde görülmektedir. Uyarılmışlık, fizyolojik sınırlar içinde olduğunda, uykunun yapısına etkisi sınırlı düzeydedir. Sınırlar aşıldığında, uyanıklıklara yol açmakta, özellikle derin uyku ve REM uykusunun sürekliliği bozulmakta, yorgun kalkılmaktadır.

En belirgin örnek, uyarılmışlığın yoğun olduğu bireylerde kalp ritminde hızlanma ve kan basıncında artmanın ortaya çıkmasıdır. Bu birliktelik uyarılmışı̆̆ın sempatik sistemin fazik aktivitesi ile ilişkili olduğundan yola çıkılarak açıklanmaktadır (5). Bu durum sık tekrarlandığında, giderek kalp damar sisteminde kalıcı değişikliklere yol açmaktadır (6).

Uyku sürekliliğinde bozulmanın yaygın bir şekilde görüldüğü üç ana tablo vardır: Uykuda periyodik bacak hareketleri, uykuda solunum bozuklukları ve psikiyatrik bozukluklar.

UPBH sonucunda gelişen uyku sürekliliğinde bozulma: UPBH, uyku sırasında genellikle bacaklarda periyodik olarak ortaya çıkan hareketlerdir. Kollarda da hareketlerin görüldüğü olgulara nadiren rastlanmaktadır. Kronik hastalığı olanlarda ve sürekli ilaç kullananlarda yaygın bir şekilde görülmektedir. Yaşlılarda, çoğu zaman bir sorun olarak tanımlanmasa da daha yaygın olduğu dikkat çekmektedir.

Uykuda solunum bozukluğu sonucunda gelişen uyku sürekliliğinde bozulma: Uyku sürekliliğinde bozukluğa yol açan sorunlar içinde horlama ve uykuda solunum bozukluklarının yeri vardır.

Psikiyatrik bozukluklar sonucunda gelişen uyku sürekliliğinde bozulma: Psikiyatrik bozukluklarda uyku sürekliliğinde bozulma yaygın bir sorundur. Uyku sırasında hareketlerin ve uyanmaların fazla oluşunda, psikolojik sorunların katkısı vardır. Kaygı bozukluklarında yoğun gerginlik sonucu gelişen uyarılmışlık, uykuya dalma kadar uyku sürekliliğini de etkilemektedir. Panik bozukluklarında, özellikle uykuda panik atakları olan hastalarda uyku sürekliliği bozulmaktadır. Depresyonda, genel anlamda yaşanan olumsuzluklar ve artan kaygı, uyku yapılanmasının tüm alanlarını etkilediği gibi bazı olgularda, neredeyse salt uyku sürekliliğinde bozulma ile de kendini gösterebilmektedir (7).

c. Uykunun Sonlanması Sorunu Sonucu Olarak Uykusuzluk Bu başık altındaki tablolar sirkadiyen ritim bozukluklarında da görülebilirse de en çok bilinen şekli, depresyonla ortaya çıkan, sabah erken uyanma ve uyuyamama ile karakterize tablolardır. Bunların dışında, sabaha doğru daha fazla görülen REM uykusu ile ilişkili bozukluklarda da görülebilmektedir.

\section{Birincil Uykusuzluğun Klinik Özellikleri}

Birincil uykusuzluk, hastalar tarafından, "dinlenmiş, günü yaşamaya hazır bir şekilde uyanamama" şeklinde ortaya konmaktadır. Bu durumu genellikle bir nedenle ilişkilendirilmektedir. Ayrıntılar incelendiğinde, bir nedene bağlı olmaksızın genellikle bu şekilde uyandıkları anlaşılmaktadır. Fiziksel hastalıklara ve psikolojik bozukluklara yatkınlık öylesine belirgindir ki; bu insanlar, kendilerini sağlıklı bir birey olarak algılamamaktadırlar. Bunun yanında, fiziksel, psikolojik ve sosyal anlamda yaşamda yer alış bozulmaktadır.

Uykusuzluk, bir tek gecede bile olsa kendini göstermektedir. İşlevsel açıdan ele alındığında uykusuzluk, biyolojik ve psikolojik işlemlerin tamamlanmamış olması, organizmanın dinlenmemiş ve yenilenmemiş bir şekilde güne başlamasına yol açmaktadır. Uykusuzluğun sürekliliği, sistemlerde kalıcı düzensizliklere, bozukluklara yol açabilmektedir. Böylece, zamanla gelişen bozukluklar, uykusuzluğun sürmesine katkıda bulunmakta, oluşan kısır döngü ile tablo pekişmektedir.

Genel sorunların ve buna eşlik edebilen fiziksel hastalıkların yanında, düşünce, duygu ve davranış alanlarına yansıyan düzensizlikler olmaktadır. Davranışlarında kııılganlık ve tepkisellik ön plana çıkabilmektedir. Uykusuzlukla ilişkilendirilebilecek değişmeler olarak en önemli nokta, "sağlıkı ve verimli bir şekilde yaşamda yer alamıyor olma" şeklinde tanımlanan durumlardır. Bu yaşantılar içindeki birey, kendisini genel anlamda, sağlıklı birisi olarak algılamamakta, sorunlarla baş edemiyor oluşu giderek çaresizliğe, tükenmişliğe yol açmaktadır. Bireyin bu algısı bile ruh sağglı̆ını bozabilecek önemli bir patoloji olarak ele alınmak durumundadır.

Birincil uykusuzluk kliniğinde önemli bir nokta da, bu insanların yorgun ve bitkin olsalar da gün içinde uyuma gereksinimi duymamalarıdır. Bu paradoksal durumdan yola çıkılarak yapılan çalışmalarda, uykusuzluk ne kadar şiddetli ise gündüz uyanıklık düzeyinin de yüksek olduğu ortaya konmuştur (8).

Sorunlara uykusuzluğu temel alarak yaklaşırken, yatkınlı̆ın ortaya konmasında iki nokta öne çıkmaktadır: Birincisi, bu insanlar bir sorunla karşılaştıklarında öncelikle uykuları bozulmaktadır. Bu bilgi, en azından, uykunun bozulmaya yatkın bir yapılanma taşıdığını düşündürmektedir. İkinci nokta, ailesel yüklülüğün varlığıdır (9).

Klinik açıdan, fiziksel hastalıklar değerlendirilmesinde birincil uykusuzluk ile olası ilişkisi dikkate alınmadığında, bu noktanın dışlanması hastalığın kronikleşmesine, ek hastalıklara, tedaviye direnç gösteren tabloların gelişmesine yol açmaktadır. Tipik olmayan fiziksel yakınmaları olanlarda, çoğu zaman salt bu tablonun parçasıymış gibi ele alınan uykusuzluk sorunu, uzun dönemde kalıcı fiziksel hastalıklara yol açabilmektedir (10).

\section{Uykusuzluğun Diğer Hastalıklarla İlişkisi}

Uykusuzluğun yaygın bir sorun olması nedeniyle çeşitli hastalıklarda rastlanması olağan gibi görülmektedir. Böylesine yaygın birliktelik, klinik tabloya benzer formlar içinde yansıdığı için de birincil uykusuzluk dikkatten kaçabilmekte, sorun, salt durumsal ya da ikincil uykusuzluk gibi ele alınmaktadır. Genel olarak, durumsal nedenlerle oluşan tablolarla birincil uykusuzluk, belirtiler açısından benzerlik taşıdığı için ayrıştırmakta güçlük vardır. Bu ayırımın dikkatten kaçması sonucunda, var olan hastalık öncelikle ele alınırken tanı, tedavi ve izleme süreçleri etkilenmektedir (11).

Uykusuzluk, sıradan bir sorun, bir hastalığın belirtisi olarak ortaya çıkabileceği gibi hastanın temel yakınması şeklinde de görülebilmektedir. Hastalıklarla birlikte oluşunda, doğrudan hastalığın bir belirtisi, eşlik eden bir dizi değişimin uzantısı, tedavinin sonucunda gelişebilen bir sorun olabileceği bilinmektedir (11). Temel sorun uykusuzluk olduğunda ise, var olan hastalık, tetikleyici, uykusuzluğun süreklilik kazanmasına yol açan ve tedaviyi güçleştiren bir faktör olarak ele alınabilir.

Bir hastalıkta uykusuzluk belirgin bir şekilde yer alıyorsa, ilk aşamada, bu hastalığın sonucu olabileceğini düşünmek kaçınılmazdır. Öte yandan, hastalığın, birincil uykusuzluğu tetikleyebileceği de söylenebilir. Uykusuzluğun birlikte olduğu hastalıklarda belirtilerin dağılımı ve şiddetini değiş̧tirebileceği, bu durumda iki tabloda da klinik görünümün, olağan formlarından farklı olabileceği bilinmektedir. 
Klinik açıdan bu birliktelik, sistematik bir şekilde ele alındığında sağlıklı sonuçlara ulaşılabilmektedir. Değerlendirme aşamasında, her belirtinin tablodaki yerinin tanımlanması, sınırların çizilmesine, etyopatogenezin açıklığa kavuşturulmasına aracılık etmektedir. Bu işlemler tamamlandığında, tedavi ve izleme planı güvenilir bir şekilde yapılabilmektedir. Bu noktadan hareketle, birincil uykusuzluğun diğer hastalıklarla birlikteliği üç temel biçimde ele alınabilir:

a. Bir hastalıktan bağımsız bir tablo olarak birincil uykusuzluk

b. Bir hastalıkta belirti olarak uykusuzluk

c. Birincil uykusuzluk sonucu olarak, zaman içinde gelişen tablolar

\section{a. Bir Hastalıktan Bağımsız Bir Tablo Olarak Birincil Uykusuzluk}

Birincil uykusuzluğun, doğrudan uyku sorunu ile başvuru olmadıkça bağımsız bir tablo olarak ele alınmasında güçlük vardır. Bir hastalık nedeniyle başvuranların yakınmaları içinde uykusuzluğu düşündürecek noktalar olduğunda, bu yönleriyle tablo değerlendirilebilir. Tanımlanan hastalığın birincil uykusuzluğu ortaya çıkarmış olabileceği dikkate alınabilir.

Toplumun üçte birinin zaman zaman da olsa fiziksel ya da psikolojik bir bozuklukla ilişkili olmaksızın uykusuzluk yaşadığından yola çıkıldığında, bu sorunla karşılaşma olasılığının ne kadar yüksek olduğu anlaşılabilecektir (12). Alevlenme ve belirli sürelerle yatışma dönemleriyle sürmekte olan birincil uykusuzluğun hastalıklar tarafından kolayca tetiklenmesi olağandır. Belirtilerin şiddeti, örtüşen ve ayrışan yönleri dikkate alınarak incelendiğinde klinik tablolar tanımlanabilecektir. Bu ayırımın yapılması, tabloların ayrı ayrı ele alınarak tedavi ve izlemenin planlanmasında yol gösterici olmaktadır.

Temel sorunun uykuyla ilişkili olduğunun ortaya çıkarılmasında iki nokta yol gösterici olabilir: Üzerinde durulması gereken ilk nokta, başvuru öncesinde de uykusuzluk sorununun varlığıdır. İkinci nokta ise, bir gece bile olsa yeterince uyumuş olma, tüm sorunların azalması ya da ortadan kalkmasına yol açmaktadır. Bir hastalığın sonucunda ya da semptomu olarak gelişen uykusuzluk tablosunda ise uykudaki değişmeleri, temel tablodaki değişme belirlemektedir.

\section{b. Bir Hastalıkta Belirti Olarak Uykusuzluk}

Genel olarak, hastalıklara uykusuzluğun sıklıkla eşlik ettiği bilinmektedir (13). Hastalık içinde uykusuzluğun belirgin bir şekilde yer aldığı tablolarda klinik görünüme yansımalar olduğu bilinmektedir. Örtük tablolarda uykusuzluğun yer alışı bir ön belirti olabileceği gibi tetikleyici bir faktör niteliğinde de olabilmektedir.

Özellikle fiziksel hastalıklarla uykusuzluk ilişkisinde kesişim noktası, hastalık sonucunda oluşan psikolojik değişmelerle açıklanabilirse de, bu tutum bir sınırlama olacaktır. Örneğin, tüm endokrinolojik hastalıklara uyku bozukluklarının eşlik ettiği bilinmektedir (14). Hipotalamus, endokrin sistemin düzenlenmesinde temel organ olmakla birlikte, uyku oluşumuna da katılmaktadır. Bu bölgedeki bozukluklar tüm alanlara yansımaktadır. Buradan yola çıkılarak kliniğe yansıyan bu örtüşme açıklanabilir. Belirti kümeleri birlikte değerlendirildiğinde, patolojinin kaynağı ayrıştırılarak etyopatogenez açıklanabilecek ve tanıya gidilebilecektir.

Diğer tablolarda da benzer özellikler dikkat çekmektedir. Örneğin, uykusuzluğun yaygın olarak görüldüğü durumlar arasında, öncelikle kronik böbrek yetmezliği, kalp damar hastalıkları, anemi başta olmak üzere bir dizi hastalık yer almaktadır. Uykuya dalma ve uyku sürekliliğinde bozulmaların ön planda olduğu bu tablolarda uyku yapısını bozan temel sorun, uykuda hareketlerin artmış olmasıdır. Uykuda artmış hareketler, gelişen nörokimyasal düzensizlikler kadar kullanılan ilaçların yol açtığı bozulmalarla da ilişkilendirilmektedir (12).

Uyku çalışmaları ile ortaya konabilen uykuda hareket artışı, metabolik, hormonal değişmelere eşlik eder niteliktedir. Bu nedenle, hastaların içinde bulundukları temel sorunun, farklı etkileşimler sonucunda uykuda patolojik değişmelere yol açabileceği dikkate almaya değer niteliktedir. Bu tabloların birincil uykusuzluktan ayrıldığı iki temel nokta vardır: Birinci nokta, birincil uykusuzlukta gündüz uykululuğu sorunu yaşanmazken bu grubun genellikle gündüz uykuluğu ve kısa da olsa uyuklamalar tanımlıyor olmalarıdır. Diğer özellik, temel hastalıktaki iyileşmenin tabloya eşlik eden uykusuzluk sorununun da ortadan kalkmasını sağlayışıdır.

Son yıllarda, "tükenmişlik sendromu" olarak adlandırılan tablonun uyku bozukluklarıyla, özellikle uykusuzlukla ilişkisi dikkat çekmiştir (15). Tablolar arasındaki etkileşim analiz edildiğinde, uykusuzluk sorunu ön planda olanlarda verimliliğin daha düşük, sosyal ilişkilerine yansıyan sorunların daha fazla olduğu sonucuna ulaşılmıştır. Bu araştırmalarda sonuç olarak uykusuzluk sorunu olanlarda, temel bozukluğun ayrıştırılarak tanımlanmasıyla, yaşamı etkileyen örtük tabloların açıklığa kavuşturulabileceği belirtilmektedir. Klinik olarak tanımlanmasında güçlük gösteren tablolar değerlendirilirken uykuya yansımaların ayrıca dikkate alınması önerilmektedir. Bu bakış açısı, tanı kadar tedavi planlanırken önceliklerin belirlenmesinde de yol gösterici niteliktedir. Böylece, bu insanların daha sağlıklı, verimli ve özgün bir şekilde yaşama katılmalarının sağlanabileceği ileri sürülmektedir.

Uykusuzluğun bir hastalıkta belirti olarakyer alışı değerlendirilirken tablolar arasındaki etkileşim dikkate alınarak yol alınabilmektedir. Bir belirti gibi yer almakla birlikte, uykusuzluğun diğer hastalıkla ilişkisinin dinamikleri incelenmeye değer niteliktedir. Uykusuzluk, diğer hastalıktaki patolojinin uyku oluşumunu bozmasıyla gelişebilmektedir. Öte yandan, böyle bir etkileşimin dışında, hastanın içinde bulunduğu durumla ilişkili olarak duygu ve düşünce dünyasında yaşadığı değişimlerin sonucunda uyku etkileniyor olabilecektir.

Bu nedenle, uykusuzluk temel bir sorun olarak tanımlanmasa da, tetiklediği ya da yol açtığı fiziksel ve psikolojik değişmelerin tabloya eklenmiş olabileceği dikkate alınarak ele alınması gerekmektedir. Çabuk yorulma, bir günü tamamlamakta güçlükler şeklinde tanımlanan genel fiziksel sorunlar yanında, duygu alanında düzensizlikler, yoğunlaşma, bellek ve düşünce süreçlerinde bozulmalar olabilmektedir (16). Tabloda dikkate değer bir durum da, diğer hastalığın yol açtığı sorunların bu patolojilerden ayrıştırılması gerekliliğidir. Uykusuz olmanın sonucunda gelişen depresif, sıkıntılı, gerginlik şeklindeki yaşantıların tek başına tedavisi planlandığında çözüm üretilememektedir. Yüzeyde görülen çökkünlük, gerginlik, kaygı gibi belirtilere yönelik tedaviler, uykusuzluk üzerinde etkili olmamakta, uykusuzluğu derinleştirebilmektedir. Bu noktanın dikkate alınması, en azından hekimin, tedavi planlamasında önceliği belirlerken uykusuzluk ile uykusuzluğa yol açan, arka plandaki bozukluğu ayrıştırması konusunda yol gösterici olmaktadır.

c. Birincil Uykusuzluk Sonucu, Zaman İçinde Gelişen Tablolar 
Birincil uykusuzluğun yıllar içinde sistemlerde bozukluklara yol açıı̆ı bilinmektedir. Genel anlamda, dejeneratif hastalıkların gelişmesine yatkınlık oluşturduğu söylenebilir. Uykunun, organizmanın yenilenmesinde vazgeçilmez rolü dikkate alındığında, bu görüşün geçerli olduğu anlaşılabilecektir.

Birincil uykusuzluk sonucu gelişen tablolarda $\mathrm{da}$, genel görünüm, diğer hastalık tablolarının belirtileri gibi ortaya çıkabilmektedir. Arka planda birincil uykusuzluk olduğunda, bunun sonucu olarak gelişmiş olan hastalığın tedavisine yoğunlaşıması, uykusuzluğun tedavi edilmemesi, hastalığın sürmesine yol açabilmektedir. Çoğu zaman incelemeler ve tedavi, var olan tabloya yönelik olarak yürütülmekte, bir kısır döngü oluşmaktadır. Bu gidiş içinde de birincil uykusuzluk kadar gelişmiş olan tablo da kronikleşme eğilimi göstermektedir. Bu nedenle, öyküde uykusuzluğun da belirgin şekilde yer aldığı ve tedavi yanıının yeterli olmadığı tablolarda birincil uykusuzluğun etiyolojide yer alıyor olabileceğinden yola çıkılarak incelemeler yapılması önerilmektedir.

Uykusuzluğun yol açtığı en belirgin fiziksel bozukluklar kalp damar sisteminde görülmektedir. Ritim bozuklukları, tansiyon yüksekliği, kalp yetmezliği şeklindeki, yaşamı doğrudan tehdit eder nitelikteki hastalıklar ortaya çıkabilmektedir (17). Bu tablolarla HBS ve UPBH arasında ilişki olduğu gösterilmiştir. Uyku çalışması yapılarak uykuda solunum bozukluğu olanların dışlandığı çalışmalarda, UPBH ile kalp atım hızında artış, hipertansiyon ve kalp yetmezliği arasında bir ilişki olduğu ortaya konmuştur (17). Bu ilişki, UPBH sırasında oluşan adrenerjik sistem aktivasyonu ile açıklanmaktadır. Benzer çalışmalarda, HBS ve UPBH ile santral sinir sisteminde (SSS) kanama ya da tromboembolik hastalıklar arasında bir ilişki olabileceği de dikkati çekmektedir. Böyle bir tablo değerlendirilirken, özellikle uyku sorunu da tanımlanıyorsa, arka planda birincil uykusuzluk olabileceği de dikkate alınabilir.

Başta diyabet olmak üzere, metabolik hastalıkların gelişebileceğine değinen çalışmalar dikkat çekmektedir (18). Birincil uykusuzluk, uzun süreli uyku yoksunluğu gibi de ele alınabileceği için metabolizmanın düzenlenmesinde yer alan ögelerin etkilenebileceği açıktır. Özellikle, metabolik sendrom, insüline dirençli diyabet tabloları ile birincil uykusuzluk arasında ilişki olabileceği düşünülmektedir. Bozulan metabolik işleyiş, kliniğe genellikle obezite şeklinde yansımakta, etyopatogenezin açıklanması da obezite temel alınarak yapılabilmektedir. Bu karmaşık görünümlü tablolar, birincil uykusuzluk dikkate alınarak değerlendirildiğinde açıklığa kavuşturulabilmektedir. Obezite irdelenirken uykuda yeme bozukluğu üzerinde de durulduğunda, bazı hastalarda, arka planda birincil uykusuzluğun varlığı ortaya konabilmektedir.

Özellikle uykuda yeme bozukluğu, leptin, grelin gibi maddelerle ilişkili olmakla birlikte hipodopaminerji sonucunda da gelişebilmektedir. Uyuduktan bir süre sonra uyanan bu hastaların ancak yemek yedikten sonra yeniden uykuya dalabildikleri dikkati çekmektedir. Gece uyku saatlerinde alınan yiyeceklerle bu hastaların kolaylıkla kilo almaktadırlar.

Uzun süreli bir sorun olan birincil uykusuzluk, gündelik yaşama yansıyan psikolojik sorunlardan tedavi gerektirecek boyutta psikiyatrik bozukluklara kadar değişen tablolara yol açabilmektedir $(19,20)$. Uykunun, bu alanları düzenleyici işlevinden yola çıkılarak, gelişen psikolojik değişmeler ve psikiyatrik bozukluklar açıklanabilmektedir. Yüzeyel olarak bellek ve bilgi işlemedeki yetersizliklerden örtük psikiyatrik tablolara kadar geniş bir alan içinde değişmeler ortaya çıkabilmektedir (21).

Öncelikle, uykusuzluğun, tüm psikiyatrik bozukluklar için bir risk faktörü olabildiği üzerinde durulmaktadır. Psikolojik işlevlerde bozulmanın yol açtığı düzensizlikle, yorgunluk, isteksizlik, yoğunlaşma güçlüğü, verimsizlik gibi bir dizi psikiyatrik belirtinin oluşmasına yol açmaktadır. Bu tür değişmelerin, psikiyatrik tanı sistemleri içindeki ölçütleri karşılayabileceği de açıktır. Klinik uygulama açısından ölçütlerin değeri yadsınamaz. Ancak, hekim, etyopatogenezi tanımlarken, belirtilerin tablo içindeki yer alışını ortaya koymak durumundadır. Böyle durumlarda uykusuzluk dikkate alınarak yapılan değerlendirme daha sağlıklı bir temele dayanmış olmaktadır. Formülasyon sonucunda, durumun birincil uykusuzluğun sonucunda geliştiği ortaya konduğunda, tanı, tedavi ve izleme işlemleri bu tanımlamaya göre yeniden planlanabilmektedir.

Salt REM uykusunun yeterli olmayışıly ilişkili olarak, psikolojik işlevlerin yenilenmemesi sonucunda oluşabilecek duygu ve düşünce süreçlerindeki belirgin değişmeler bir psikiyatrik bozukluk gibi de kendini gösterebilmektedir (22). Bu düzensizliklerin zaman içinde psikiyatrik bozukluk olarak sürmesi de beklenebilir. $\mathrm{Bu}$ nedenle, tekrarlayan ve tedavilere yeterli yanıt vermeyen psikiyatrik tabloların arka planında birincil uykusuzluğun yer alıyor olabileceği düşünülmektedir. Psikiyatrik bozukluklarda kullanılan ilaçların sedatif etkileri ile uykuda düzenlemeler olması sonucunda tedavinin başlangıç dönemlerinde ortaya çıkan iyileşmenin sonraki dönemlerde sürmemesi, hatta alevlenmeler olması bu görüşü desteklemektedir. Bir diğer gözlem de tedavi planlanırken birincil uykusuzluk ya da ilişkili patolojiler dikkate alındığında tedavinin daha başarılı sonuç vermesidir.

\section{Uykusuzluğun Psikiyatrik Bozukluklarla İlişkisi}

Psikiyatrik bozuklukların "atipik" başlığı altında yer alanlarının dışındakilerde uykusuzluk son derece yaygındır. Bu örtüşme, belirti düzeyinde olmakla sınırlı değildir. SSS'deki sorunların iki durumun da oluşmasında belirleyişi üzerinde durulabilir. Bu bakış açısı, belirtilerin ortak ögelerini ortaya koyarken, etkileşimin anlaşılmasına da katkıda bulunmaktadır. Etkileşim sonucunda belirti kümelerinin yapısı ve şiddeti değişmektedir. Uykusuzluk ya da psikiyatrik bozukluktan birinde sağlanan düzelme diğerinin de iyileşmesine katkıda bulunmaktadır. Bu nedenle, klinik anlamda uyku bozukluğunun düzelmesi tedavi sürecinde olumlu bir gösterge olarak kabul edilebilmektedir (23).

$\mathrm{Bu}$ ilişki nedeniyle uykusuzluk ele alınırken psikiyatrik bozuklukların ayrıca dikkate alınması gerekmektedir.

Uykusuzluk, psikiyatrik bozukluklarda, bir ön belirti olabileceği gibi tetikleyici bir faktör olarak da yer alabilmektedir. Özellikle psikiyatrik bozukluğun yatışma dönemlerinde ortaya çıkan uykusuzluğun, alevlenmenin habercisi ya da tetikleyicisi olduğu bilinmektedir.

Birincil uykusuzluğun alevlenme dönemlerinde, yol açtığı psikolojik düzensizliklerin daha yoğun bir şekilde yaşanıyor olması doğaldır. Ancak, psikiyatrik bozuklukların ayrıca bir hastalık olarak tabloya eklendiği durumlar olabileceği düşünülebilir. $\mathrm{Bu}$ olasılıklar dikkate alınarak incelemelerin düzenlenmesi, değerlendirme sürecinde yol gösterici olmaktadır.

Psikiyatrik bozukluğun bir belirtisi olarak görülen uykusuzluğun tabloda yer alışını açıklamak daha açık ve kolay olmaktadır. Ayrı bir tablo olduğu durumlar ise görece karmaşık bir görünüm 
sergilemektedir. Birincil uykusuzluğun açık ya da örtük bir durum olarak yer aldığı tablolarda, psikiyatrik bozukluk belirtilerinin görünüm ve yoğunluğu olağan biçimlerinden farklı olabilmektedir. Özellikle duygu ve düşünce süreçleriyle ilişkili yaşantıların daha belirgin bozulmalar gösterdiği söylenebilir. Bu değişim, birincil uykusuzluk sonucu zaman içinde oluşan bozulmaların psikiyatrik tabloya eklenmiş olması şeklinde de düşünülebilir. Tabloların gidişi ve tedavi yanıtı izlendiğinde gelişmelerin ikisindeki değişmelerle doğrudan ilişkili olabileceği dikkat çekmektedir.

Uykusuzlukla psikiyatrik bozukluk ilişkisinin en yoğun olduğu tablo depresyondur. Bu nedenle bu nokta ayrı bir başlık altında ele alınmaya değer görünmektedir. Depresyonda, uyku yapısındaki değişme, tanı ve tedavi planlaması açısından da değer taşımaktadır.

Uykusuzluk ve depresyon toplum içindeki yaygınlığı açısından büyük ölçüde benzemektedir. Bu nedenle, birlikte görülmeleri olağan bir durum olarak kabul edilebilir (24). Uykusuzluk, bir yanıyla, depresyon belirtilerine yol açarken depresyonda da yaygın şekilde uykusuzluk görülmektedir. Yine de temel bir psikiyatrik bozukluk olarak depresyon, kendi içinde bütünlük taşısa da hastaların yakınmaları ve hastalığın belirtileri, birincil uykusuzluk sorunu olanların yaşantılarıyla büyük ölçüde örtüşmektedir. Depresyonla uykusuzluk birlikteliğinin üzerinde durulmasının bir yönü de, iki tablonun da alevlenme ve yatışma dönemleri gösteriyor olmalarıdır. Özellikle ikisinin de alevlenme dönemleri örtüştüğünde, ağır tablolar ortaya çıkmaktadır. Bu değişmelerin, en azından kliniğe yansıyan yönleri açısından birbirlerini olumsuz yönde etkilediği dikkati çekmektedir.

Klinik görünüm açısından böylesine örtüşme, özellikle uykusuzluğun tedavi edilmemiş olması sonucu gelişen fiziksel ve psikolojik "iyi olamama" durumundaki karmaşanın ve belirsizliğin derinleşmesine yol açmaktadır. Bu noktada, uykusuzluğun, hastalığın şiddeti ile ilişkisi sorgulanabilir. Çoğu zaman hastalıktaki düzelme ile uykunun düzelmesi ilişkilidir. Uykunun düzelmesinin de hastalıktaki düzelmenin göstergesi olabileceği açıtır.

Uykusuzluğun depresyona bağlı olduğu durumlarda, değişim, depresyondaki değişime paralel olmaktadır. İki tablonun örtüştüğü durumlar dışarıda bırakılırsa, birbirini tetikleyen ya da yatıştıran özellikler, hasta değerlendirilirken ve izlenirken dikkat çekmektedir. Örneğin, ilk depresyon atağı içindeki hastaların \%40'ında uykusuzluğun ilk belirti olarak görüldüğü ortaya konmuştur. Tekrarlayan depresyonda ise uykusuzluk, olguların yarısından fazlasında depresyonun habercisidir (25).

Öte yandan uyku yoksunluğunun kısa dönemde antidepressif etki gösteriyor olması, uykusuzluğun, depresyonla ilişkisinin salt bir belirti bağlamında ele alınmasının dışında, dinamik bir ilişki olabileceğini düşündürmektedir. Bu ilişkilerin dinamikleri, nörokimyasal, nöroendokrin incelemeler ve uyku çalışmalarıyla ortaya konmaktadır (26).

Depresyon ile uykusuzluk arasındaki güçlü ilişki, özellikle yaşlı hastalarda daha da ön plana çıkmaktadır. Depresyonun, uykusuzluk sorunu olanlarda, bu sorunu olmayanlara göre belirgin şekilde daha sık görülmesi, bu savı destekler niteliktedir (27). Bu ilişkide dikkati çeken bir diğer nokta, uykusuzluk sorunu, depresif hastada daha yoğun olarak ortaya çıkmakta, tedavi yanıtı da daha zayıf olmaktadır. Birincil uykusuzluğu olan depressif hastalarda da tedaviye yanıt daha geç oluşmakta ya da belirgin bir şekilde aksamaktadır.
Uyku bozukluğunun depresyon oluşumu için bir risk faktörü olduğu, uykusuzluktan depresyona bir gidiş olduğu düşünülmektedir. Altmış beş yaş üstü deneklerde yapılan bir çalışmada depresyon tedavisinden sonra kalan uyku bozukluğu yakınmasının depresyonun tekrar ortaya çıkmasına neden olduğu ortaya konmuştur (25).

Psikotik bozukluklarda uykusuzluk tabloya eşlik etmesinin ötesinde, genellikle alevlenme ya da yeni bir atağın habercisi olarak görülmektedir.

Psikiyatrik bozukluklarda uykusuzluğun, birincil uykusuzlukta psikiyatrik belirti ve bozuklukların bir sistematik içinde ele alınmasının, tanı, tedavi ve izleme açısından daha sağlıklı sonuçlar vereceği ileri sürülebilir.

Genel anlamda birincil uykusuzluğun, bir hastalık olarak tüm sistemlere yansıyan bozulmalara yol açtığı söylenebilir. Eşlik ettiği tablolarda da diğer hastalığın tablosunu etkilediği dikkat çekmektedir. Bu nedenle, belirgin bir şekilde uykusuzluk yakınması bulunan hastalarda değerlendirme sürecinde birincil uykusuzluğun da dikkate alınması daha sağlıklı bir tutum olacağı söylenebilir. Klinik açıdan üzerinde durulmaya değer iki nokta daha vardır: Çocukluk çağı ve yaşlılıkta birincil uykusuzluk.

\section{Çocukluk Çağı Birincil Uykusuzluğu}

Erken çocukluk döneminde uykusuzluk, daha çok uyku saatine karşı direnç, kendi başına uyumama şeklinde kendini göstermektedir (1). Bu dönemde uyku düzenlemelerine özen gösterilmemesi, zaman içinde kalıcı olabilecek tabloların gelişmesine yol açabilmektedir.

İzleme çalışmalarında, çocukluk dönemi uykusuzluğu ile iki nokta arasında ilişki ortaya çıkmıştır: Birincisi, düşük doğum ağırlıklı bebeklerde genel olarak uyku bozuklukları ve özel olarak da uykusuzluğun gelişme riski yüksek bulunmuştur. İkinci nokta ise, gebelik döneminde annenin alkol kullanmasının aynı riskleri arttırdığı dikkat çekmektedir. Bu noktalardan hareketle, araştırmacılar, doğum öncesi gelişim kusurlarının uyku bozukluklarına yol açmakta olduğunu vurgulamışlardır. Uykusuzluk sorununun ön planda olduğu çocuklarda daha çok sirkadiyen ögenin etkilenmiş olabileceği üzerinde durulmaktadır. Bu etkileniş, yatkınlıkla açıklanabileceği gibi düzensiz bir şekilde uyuma sonucunda da gelişebilmektedir (28).

Çocukluk çağındaki uykusuzluk tablolarının fiziksel gelişimde aksama, okul başarısızlığı ve uyum sorunlarıyla ilişkili olduğu dikkat çekmektedir. Uykunun biyolojik ve bilişsel işlevlerin düzenlenmesine aracılık ettiğinden yola çıkıldığında bu tabloların gelişimi anlaşılabilmektedir.

Uykunun ilk saatlerinde yer alan derin uyku sırasında salgılanan büyüme hormonu protein sentezini düzenlemektedir. Özellikle çocukluk çağında fiziksel gelişim için gerekli olan bu düzenleme eksik kaldığında, biyolojik ve psikolojik alanlarda aksamalar olması beklenebilir. Gelişimdeki aksama, kliniğe, sık hastalanma ve fiziksel gelişim açısından yaşıtlarından geride oluş şeklinde yansımaktadır. Uykusuzluk nedeniyle bilişsel işlevlerin aksaması da bellek, bilgi işleme ve duygu düzenleme süreçlerinde bozulmaya neden olmaktadır. Bunların sonuçları da öğrenme süreçlerine yansıdığı gibi sosyal ilişkilerde de bir dizi düzensizlikle kendini göstermektedir.

Çocukluk çağında uykusuzlukla ilişkili bir nokta da HBS tablolarıdır (29). Bu dönemde tanımlanan yakınmalar, genellikle "gelişme/ büyüme ağrıları" olarak kabul edilmektedir. Çocukluktaki HBS 
tablolarının dikkat eksikliği hiperaktivite bozukluğu ile karışma olasılığı yüksektir. Sürekli olarak oturarak ders dinlemek zorunda kalan bu çocuklar, bacaklarındaki huzursuzlukla başedebilmek için hareketler yapmak zorunda kalmaktadırlar. Bu durum da hiperaktivite olarak adlandırılabilmektedir. Uykuya da yansımaları olan HBS, çocuklarda okul başarısının düşük olmasına yol açabilmektedir.

Öte yandan, iki tablonun birlikte görülebileceği de bilinmektedir. Bu nedenle, dikkat eksikliği hiperaktivite tabloları değerlendirilirken arka planda HBS olabileceği de düşünülerek ele alınması daha sağlıklı olmaktadır. HBS tablolarındaki ailesel yüklülüğün, bir dizi metabolik düzensizliğin dikkate alınması tanı açısından yol gösterici olmaktadır.

\section{Yaşlılık Dönemi Birincil Uykusuzluğu}

Yaşılıarın yaklaşık üçte biri uykusuzluk sorunu yaşamaktadır. Çoğu zaman çevredekiler onların uyuduğunu gözleseler de uykuda dinlenememekten yakınmaktadırlar. Sağlıklı yaşlılarda yapılan uyku çalışmalarında, derin uykunun azalmış olduğu gösterilmiştir. Yapıdaki bu değişmelere delta dalgalarında azalma eşlik etmektedir (30). Bu veri, onların dinlenememiş olma şeklindeki yakınmalarını açıklamaktadır. Bunun dışında, uykularını etkileyen fiziksel, psikolojik, sosyal faktörler ve kullanılan ilaçlar da dikkate alındığında yaşlılarda uykusuzluk sorunun yaygınlığı anlaşılabilmektedir (31).

Yaşlıda, melatonin üretiminin azalması yanında, nöroendokrin sistemdeki sirkadiyen ritme paralel işleyiş de değişmektedir. Bunlar, uykunun ana yapısının ve kalitesinin bozulmasına neden olabilecek faktörlerdir. Değişmeler bütün olarak ele alındığında, sağlıklı bir uyku için gerekli olan koşulların büyük ölçüde etkilenmiş olduğu dikkati çekmektedir (18).

Yaşlı popülasyonda yapılan çalışmalarda, kadınlarda daha fazla olmak üzere, yarısından fazlasının uykuyla ilişkili bir sorunu olduğu saptanmıştır. Aynı yaş grubunda, çoğunlukla uykuya dalma ve uykuyu sürdürme sorunu tanımlanmakta, popülasyonun yaklaşık \%20'sinde sabah erken uyanma yakınması bulunmaktadır (31).

Yaşlıda uykusuzluğu açıklayabilecek nedenlerin başında, biyolojik değişmeler yer almaktadır. Bu nedenle, fiziksel hastalıkların öncelikle ele alınması önem taşımaktadır. Psikolojik sorunlar birincil nitelikli olabileceği gibi daha çok, fiziksel hastalıklara tepki, kullanılan ilaçların sonucu olarak ortaya çıkabilmektedir. Hastalıklar içinde, hipodopaminerji başlı̆ı altında ele alınabilecek parkinson hastalığı yanında HBS de önemli bir yer almaktadır. Yaşılııkta azalmakta olan dopamin, semptomatik ya da örtük HBS tablosunun ortaya çıkısıını tetikleyerek uykusuzluğa yol açabilmektedir.

Yaşlı popülasyondaki uykusuzluk sorununun önemli bir noktasını da yaşam biçimindeki değişiklikler oluşturmaktadır. Fiziksel aktivitenin azalması en azından uyku için temel öğe olan homeostatik faktörün yeterli olmamasına yol açmaktadır. Üstelik kısa süreli de olsa gündüz saatlerinde uyumaları, homeostatik faktör kadar sirkadiyen faktörü de etkilemektedir. Sirkadiyen ritmin düzenlenmesini bozan bir nokta da, genellikle kapalı ortamlarda zaman geçiriyor olmalarıdır. Bu yüzden gündüzleri güneş ışığından uzak kalmakta ve ritim düzenlemesi dolaylı bir biçimde aksamaktadır.

Yaşıllarda ilaç kullanımını yaygın olduğu bilinmektedir. Illaçların büyük bölümü uyku bozukluklarına yol açmaktadır.
Uykusuzluk tablolarında, son yıllarda dikkati çeken bir tablo ayrıca ele alınacaktır: Ölümcül ailesel uykusuzluk (Fatal familial insomnia).

\section{Ölümcül Ailesel Uykusuzluk}

Ölümcül ailesel uykusuzluk, ilerleyici ve ailesel özellikler gösteren, başlamasından birkaç ay sonra ölüme yol açan bir tablodur. Tablo, uykusuzluk ile başlamakta, stupor, otonomik disfonksiyon ve ekstrapiramidal sistem patolojileri ile sürmektedir. Ilk olgular İtalya'da bir ailede bildirilmiştir (32). Sonraki yıllarda diğer ülkelerde de ölümcül ailesel uykusuzluk olguları olduğu bildirilmiştir. Genetik olarak otozomal dominant bir geçiş göstermektedir. Otopsi sonuçlarında talamustaki anterior ve dorsomedial çekirdeklerde dejenerasyon saptanmıştır. Başlama yaşı 40-50 arasında olup günümüze kadar tanı konmuş olguların tümü 7-18 ay içinde kaybedilmiştir (32). Bilinen tedavisi yoktur.

Sonuç olarak; uykusuzluk, bireylerin yaşam kalitesini etkileyen, eşlik ettiği tabloların yapısını, gidişini ve prognozunu kötüleştiren ciddi bir sağlık sorunudur. Yaygınlığı ve sonuçları dikkate alındığında sistematik bir şekilde ele alınması gereken bir tablodur. Gündelik uygulamada, hekimlerin karşısına genellikle bir hastalığın belirtisi ya da doğrudan bir sorun alanı olarak çıkabilmektedir. Bu fark, hasta tarafından açık bir şekilde ortaya konabileceği gibi, örtük ve karmaşık tablolarda durumu ele alış, bakış açısına göre değişebilmektedir. Değerlendirme sürecinde sorunun, salt uyuyamama olmaktan öte, uyku oluşumunun bozulmasıyla ilişkili olduğu dikkate alındığı takdirde, tablonun tanımlanmasında adım atılabilecektir. Bu bakış açısı içinde incelemeler derinleştirilerek ilerlenebilir ve her aşamada uykuyla ilişkili sorunlar dikkate alınarak durum daha geniş çerçevede formüle edilmiş olur. Böylece uykusuzluk sıradan bir görünümde kendini gösteriyor olsa da iç dokusu ve dinamikleri irdelendikçe anlaşılabilir. Tedavi amacıyla yapılacak işlemler de bu süreçte belirlenebilmektedir.

\section{Kaynaklar}

1. American Sleep Disorders Association (ASDA). (2005) International Classification of Sleep Disorders, Diagnostic and Coding Manual. Illinois: American Academy American Sleep Disorders Association of Sleep Medicine, Westchester.

2. Allen RP, Picchietti D, Hening WA, Trenkwalder C, Walters AS, Montplaisi J, Restless Legs Syndrome Diagnosis and Epidemiology workshop at the National Institutes of Health, International Restless Legs Syndrome Study Group. (2003) Restless legs syndrome: diagnostic criteria, special considerations, and epidemiology. A report from the restless legs syndrome diagnosis and epidemiology workshop at the National Institutes of Health. Sleep Med. 2: 101-19.

3. Aydın H, Özgen F. (1998) Uyku bozuklukları, Psikiyatri Temel Kitabı. Içinde: Güleç C, Köroğlu E (eds). Hekimler Yayın Birliği, Ankara, 681-96.

4. Aydın H. (2000) Uyku: Yapısı ve işlevi, in Multidisipliner Yaklaşımla Beyin ve Kognisyon, Karakaş S, Aydın H, Erdemir C, Özesmi Ç (eds). Çizgi Tıp Yayınevi, Ankara, 103-12.

5. Bonnet MH, Arand DL. (1997) Heart rate variability: sleep stage, time of night, and arousal influences. Electroencephalogr Clin Neurophysiol, 102: 390-96.

6. Katz DA, McHorney CA. (2002) The relationship between insomnia and health-related quality of life in patients with chronic illness. J Fam Pract, 51: 229-35. 
Yetkin S. ve Aydın H.

Bir Semptom ve Bir Hastalık Olarak Uykusuzluk

7. Aydın H, Sütçügil L, Özgen F. (2001) Insomnia. T Klin Psikiyatri, 2: 98-102.

8. Bonnet MH, Arand DL. (2010) Hyperarousal and insomnia: State of the science. Sleep Med Rev, 14: 9-15.

9. Andretic R, Franken P, Tafti M. (2008) Genetics of sleep. Annu Rev Genet, 42: 361-88.

10. Roth T. (2007) Insomnia: Definition, prevalence, etiology, and consequences. J Clin Sleep Med, 3: 7-10.

11. Billiard M, Bentley A. (2004) Is insomnia best categorized as a symptom or a disease? Sleep Med, 5: 35-40.

12. Buysee DJ. (2008) Chronic insomnia. Am J Psychiatry, 165: 678-86.

13. Gisason T, Almquist M. (1987) Somatic disease and sleep complaint: an epidemiological study of 3,201 Swedish men. Acta Med Scan, 221: 475-81.

14. Vgontzas AN, Bixler EO, Lin HM. (2001) Chronic insomnia is associated with nyctohemeral activation of the hypothalamicpituitary-adrenal axis: clinical implications. J Clin Endocrinol Metab, 86: 1787-94.

15. Armon G, Shirom A, Shapira I, Melamed S. (2008) On the nature of burnout-insomnia relationships: A prospective study of employed adults. J Psychosomatic Research, 65: 5-12.

16. Aydın H. (2000) Beynin biyokimyasal işlevleri: Nörotransmitterler ve yolakları, psikiyatride kullanılan ilaçlar ve etki yolları, in Multidisipliner Yaklaşımla Beyin ve Kognisyon. Karakaş S, Aydın H, Erdemir C, Özesmi Ç (eds), Çizgi Tıp Yayınevi, Ankara, 71-81.

17. Walters AS, Rye DB. (2009) Review of the relationship of restless legs syndrome and periodic limb movements in sleep to hypertension, heart disease, and stroke. Sleep, 32: 589-97.

18. Ohayon MM, Zulley J, Guilleminault C. (2001) How age and daytime activities are related to insomnia in the general population: consequences for older people. J Am Geriatr Soc, 49:360-66.

19. Riemann D. (2007) Insomnia and comorbid psychiatric disorders. Sleep, 4: 15-20.
20. Derman S, Williams RL, Karacan I. (1981) Sleep Disorders and their Psychiatric Significance. In Fann WE, Karacan I, Pokorny AD, Williams RL (eds): Phenomenology and Treatment of Psychophysiological Disorders. New York, Spectrum, 315-54.

21. Aydın H. (2013) Uykunun psikolojik işlevi. Uykusuzluk. 1. Baskı. Ankara: Bağlam Yayınları, 54-5.

22. Aydın H, Özgen F. (1992) Effect of Imipramine on REM: paradoxical or parallel? European Neuropsychopharmacology, 2: 389-91.

23. Aydın H. (2013) Psikolojik etiyoloji. Uykusuzluk. 1. Baskı. Ankara: Bağlam Yayınları, 137-40.

24. Staner L. (2010) Comorbidity of insomnia and depression. Sleep Med Rev, 14: 35-46.

25. Kennedy GJ, Kelman HR, Thomas C. (1991) Persistence and remission of depressive symptoms in late life. Am J Psychiatry, 148: 174-8.

26. Bixler EO, Kales A, Vgontzas AN. (1989) Sleep deprivation effects on the activity of the hypothalamic-pituitary-adrenal and growth axes: potential clinical implications. Clin Endocrinology, 51: 205-15.

27. Livingstone G, Blizard B. (1993) Does sleep disturbance predict depression in elderly people? A study in inner London. Br J Gen Pract, 43: 445-8.

28. Ohayon MM, Sagales T. (2010) Prevalence of insomnia and sleep characteristics in the general population of Spain. Sleep Med, 11: 1010-8.

29. Turkdogan D, Bekiroglu N, Zaimoglu S. (2011) A prevalence study of restless legs syndrome in Turkish children and adolescents. Sleep Med, 12: 315-21.

30. Amzica F, Steriade M. (1998) Electrophysiological correlates of sleep delta waves. Electroencephalogr Clin Neurophysiol, 107: 69-83.

31. Ganguli M, Reynolds CF, Gilby JE. (1996) Prevalence and persistence of sleep complaints in a rural older community sample: the MOVIES project. J Am Geriatr Soc, 44: 778-84.

32. Lugaresi E, Medori R, Montagna P, Baruzzi A, Cortelli P, Lugaresi A, Tinuper P, Zucconi M, Gambetti P. (1986) Fatal familial insomnia and dysautonomia with selective degeneration of thalamic nuclei. $N$ Engl J Med, 315: 997-1003. 